\title{
Environmental Efficiency Assessment of the U.S. Pulp and Paper Industry Using an SBM-DEA Model
}

Yali $\mathrm{Li}^{\mathrm{a}, \mathrm{b}, *}$ and Jianhua Xiao ${ }^{\text {a }}$

The pulp and paper industry contributes to the economic development of the U.S., producing goods that meet primary needs. However, this sector must operate in a balance with the environment to ensure ecological preservation. Proposing a non-radial slacks-based measure - data envelopment analysis (SBM-DEA) approach, this study assessed the environmental efficiency of the pulp and paper industry in the U.S. from 2015 to 2018. External environmental impacts and random interferences on efficiency assessment were explored by using a stochastic frontier approach (SFA) regression. This study revealed that the U.S. pulp and paper industry was highly non-eco-efficient in the period evaluated, presenting an average environmental efficiency value of 0.509 . Also, it is suggested that a total of 2.967 million metric tons of $\mathrm{CO}_{2 \text { eq }}$ emissions were in excess of those that were estimated based on an assumption of perfect environmental efficiency from 2015 to 2018 in the U.S. pulp and paper Industry. Based on the analysis of input and output slacks and the external environmental factors which reflect the environmental features of each decision-making unit (DMU), these facilities should substantially reduce $\mathrm{CO}_{2}$ eq emissions and enhance the resources-allocation efficiency for improving the environmental efficiency of the U.S. PPI.

Keywords: Environmental efficiency; Carbon emissions reduction; P \& P industry; Slack-based measure; Data envelopment analysis

Contact information: a: School of Finance, Taxation and Public Administration, Jiangxi University of Finance and Economics, Nanchang, 330013 China; $b$ : Department of Forest Biomaterials, North Carolina State University, P. O. Box 8005, Raleigh, NC 27695-8005 USA;

*Corresponding author: yli256@ncsu.edu

\section{INTRODUCTION}

The effects of climate change are seen globally on a large-scale. Climate change affects society and ecosystems in different ways, such as severe temperatures, flooding, and changes in the quality of the air. As climate change concerns grow, a series of actions to combat the problem have emerged to understand and reduce its causes. Recently, the Climate Action Summit, held in September 2019, had as a central purpose to develop plans to reduce greenhouse gas emissions by $45 \%$ over the coming decade, and net to zero by 2050 (United Nations 2019). The presence of greenhouse gases (GHGs) in the atmosphere, such as carbon dioxide, methane, nitrous oxide, and chlorofluorocarbons, leads to the global warming effect. Global warming potential (GWP) relates how much energy will be absorbed by one ton of emissions of these gases over a period of time, compared to one ton of carbon dioxide. Thus, when considering different gases of increasing GWP, the more they will warm the earth in contrast to carbon dioxide (EPA 2017).

The U.S. energy demand is mainly satisfied by fossil fuel combustion, which causes massive carbon dioxide $\left(\mathrm{CO}_{2}\right)$ emissions (U.S. EIA 2018). Although $\mathrm{CO}_{2}$ is the main contributor to GHGs, accounting for about two thirds, other gases such as methane $\left(\mathrm{CH}_{4}\right)$ 
and nitrous oxide $\left(\mathrm{N}_{2} \mathrm{O}\right)$ are also generated during fuel combustion and contribute to GHGs emissions (EPA 2018). According to the most recent data from the Global Carbon Project 2018, the U.S. is the second-largest emitter of $\mathrm{CO}_{2}$. Also, for the sources of GHG emissions, in 2017, the US total emissions were estimated to be 6.5 billion metric tons of

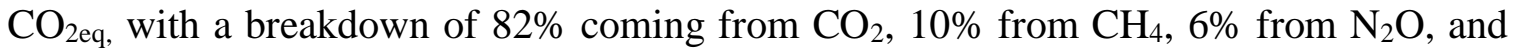
$3 \%$ from other fluorinated gases. For the U.S. pulp and paper Industry, the GHGs emissions have been estimated to be 35.5 million metric tons of $\mathrm{CO}_{2 \mathrm{eq}}$ (EPA 2017). Therefore, to reduce the environmental impact, it is worthwhile to estimate the GHGs emissions and assess the environmental efficiency in the U.S. pulp and paper industry, which may provide useful information for researchers who are likely to investigate in this field.

Few studies have analyzed efficiency by using cross-sectional data instead of panel data in the U.S. pulp and paper industry from a productivity efficiency perspective. Many previous studies have preferred to apply radial programs into the efficiency analysis, which cannot estimate all the technical inefficiencies of greenhouse gas emissions. Thus, the purpose of this study is to fill in the gap by using a slack-based efficiency approach with non-radial measure for estimating the environmental efficiency of the U.S. pulp and paper industry and exploring its slacks of inputs and outputs to determine the optimal values for capital, labor, energy usage, and $\mathrm{CO}_{2 \text { eq }}$ emissions.

\section{Literature Review}

The assessment of environmental performance has been the focus of research worldwide in the past several decades. Shephard (1970) firstly introduced the concept of "environmental efficiency". Since then, there have been various measurements and evaluations of environmental efficiency analyzed by scholars. Some researchers prefer to assess environmental efficiency by using an environmental performance index (EPI) (Färe and Grosskopf 2004; Kortelainen 2008; Vachon 2012). Life Cycle Assessment (LCA) methods have been also applied into estimate carbon dioxide equivalents $\left(\mathrm{CO}_{2} \mathrm{eq}\right)$ in certain sectors. This approach accounts for contributions to pollution from the cradle to landfill, and it also has been used to evaluate $\mathrm{CO}_{2} \mathrm{eq}$ emissions as the input indicator of environmental efficiency (Miettinen and Hämäläinen 1997; Lozano et al. 2010; Olander 2012; Poeschl et al. 2012; Hawkins et al. 2013; Vázquez-Rowe and Iribarren 2015; Carvalho et al. 2014).

Environmental efficiency analysis often employs the data envelopment analysis model (DEA). The DEA method is a non-parametric approach that can achieve an optimal linear combination of multiple inputs and outputs, which has the advantage of ignoring the imposition of a function form (Zhu 2004). Therefore, DEA could make the estimation of efficiency easier. DEA was first designed by Charnes et al. (1978) and called the CCR model as a combination analysis tool of input and output based on relative efficiency. It is different from the radial models, which have been widely employed, as it applies the parametric approach into efficiency assessment. Wei et al. (2007) estimated the energy efficiency of China's specific industry using DEA models. However, conventional DEA in the application may only take the desirable outputs into account. Conventional DEA does not consider environmental efficiency analysis results from "bad" or "pollutants" as inputs to the model. For instance, it may cause biased results on the assessment of the environmental efficiency due to ignoring the impacts of undesirable gaseous outputs such as $\mathrm{CO}_{2}$ or $\mathrm{SO}_{2}$ as well as pollutants in the treated wastewater (He et al. 2013; Chen et al. 2015).

In this context, the slacks-based measure (SBM) models were introduced by Tone 
(2001) and Pastor et al. (1999). The SBM-DEA model is a non-radial measurement under the constant returns-to-scale (CRS) and the variable returns-to-scale (VRS) assumption. It allows inputs, undesirable outputs, and desirable outputs by individuals to obtain factor efficiencies based on non-uniform inputs and outputs. Shi et al. (2010) applied DEA under the constant returns-to-scale (CRS) and the variable returns-to-scale (VRS) models to estimate the industrial environmental efficiency in some provinces of China, considering waste gases as undesirable outputs. Park et al. (2016) estimated environmental and carbon efficiency of the U.S. transport sector by using a lack-based data envelopment method. Chen and Jia (2017) selected sulfur dioxide emissions and industrial solid waste as undesirable outputs and made the environmental efficiency evaluation of China's industry. Guo et al. (2011) analyzed the environmental efficiency and reduction of carbon dioxide emission in 30 provinces of China through SBM-DEA methods. Wang et al. (2011) analyzed $\mathrm{CO}_{2}$ emissions for China with an expanded DEA efficiency measurement. Zhang et al. (2008) assessed the industrial environmental efficiency of large provinces in China, considering $\mathrm{CO}_{2}, \mathrm{CH}_{4}, \mathrm{SO}_{2}$, and other emissions as input for a DEA model with variable returns to scale. Ramanathan (2005) estimated the energy efficiency of the transport sector in India by using the DEA model. Önüt and Soner (2006) assessed the energy efficiency in 32 five-star hotels in the Antalya Region of Turkey while employing DEA with the nonfunction linear programming model. Lee et al. (2014) evaluated the environmental efficiency of port cities and considered input of input, desirable output of GDP, and undesirable outputs of pollutant emissions as indicators of the SBM-DEA model. Chang et al. (2014) expanded upon an SBM model with the weak disposability assumption to analyze the economic and environmental efficiency of international airlines. Some researchers adjusted the SBM-DEA model with advanced SBM-DEA software to analyze the internal process of DMUs (Tone and Tsutsui 2009; Cook et al. 2010; Tone and Tsutui 2010; Li et al. 2017; Wu et al. 2019).

As for the Pulp and Paper Industry (PPI), a number of researchers have estimated PPI's environmental efficiency. For instance, Yu et al. (2016) assessed the environmental efficiency of 16 provinces' PPI in China and compared the disparity between efficient and inefficient DMUs by using SBM-DEA and ML methods. Ashrafi et al. (2013) applied a simulated model and analyzed PPI's GHG emissions with the removal of excess nitrogen in the wastewater plants. Hubbe et al. (2016) reviewed comprehensive approaches for wastewater treatment, which could help the PPI to eliminate higher levels of pollutant by proposing advanced treatment and improve environmental efficiency.

The goal of the present work was to analyze the impacts of the external environment and random factors on sustainable development in the U.S. PPI. In this study, the Stochastic Frontier Analysis (SFA) proposed by Aigner et al. (1977) was used to assess environmental efficiency more accurately by accounting for external environmental variables and removing random interference factors. The traditional SBM-DEA model does not take external environmental and random factors impact into account, leading to deviations in the adjustment of inputs slack and undesirable output slack (Zhang and $\mathrm{Bu}$ 2017). In addition, the waste factors have extent effects on the U.S. PPI sustainable practice.

As shown by the review of the literature, SBM software and SFA regression have been widely used to evaluate the environmental efficiency of the models involving undesirable outputs. Few pieces of research have been applied to the evaluation of the environmental efficiency of PPI facilities from a micro perspective. Given the scenarios of the environmental impact of the U.S. pulp and paper industry, $\mathrm{CO}_{2} \mathrm{eq}$ emissions should be specifically treated as undesirable outputs. This conforms to the realistic production 
process of PPI from manufacturing, fuel combustion, and landfill, and the efficient result will be more convincing to reveal the true environmental performance of the U.S. PPI. In this study, the DEA model was expanded based on the output-oriented slacks-based measurement (SBM) approach under the variable returns to scale (VRS) assumption, to estimate the environmental efficiency of the U.S. pulp and paper Industry. This study explored the excess in inputs and undesirable outputs that could potentially lead to reducing the carbon emissions of this sector. Additionally, the impacts of external environmental factors on the slacks of inputs and outputs by using SFA method was explored. It is expected that the results reflect the actual pulp and paper industry development in the U.S. and provide policy implications relative to $\mathrm{CO}_{2}$ eq emissions reduction while maximizing benefits.

\section{EXPERIMENTAL}

\section{Methodology}

This study developed a framework for measuring the environmental efficiency of 130 pulp and paper facilities in the U.S. from 2015 to 2018 via slack-based measurement (SBM) with undesirable outputs and explored the influences of the external environment and random factors on slack of inputs and outputs.

\section{Slacks-based Measure for DEA}

Following Zhou et al. (2006), Chang et al. (2013), and Hong and Shi (2014), this paper proposes and expands an SBM-DEA framework by using the undesirable outputs as an objective function and the restricted function. It has three variations, i.e., input-oriented, output-oriented, and non-oriented, which can be estimated under constant returns-to-scale (CRS) and the variable returns-to-scale (VRS) assumption (Tone 2001; Tone and Sahoo 2003). While considering a bad output in the model, it is noted that the efficiency value of each decision-making unit (DMU) could be improved by increasing the desirable output, reducing the excess in inputs, or decreasing the undesirable outputs (Zhang et al. 2011; Chang et al. 2014).

Suppose that a system has $\mathrm{k}=\{1, \ldots, \mathrm{n}\}$ decision DMU and that each "k" uses " $\mathrm{j}$ " inputs to produce " $\mathrm{e}$ " desirable outputs and generate " $\mathrm{f}$ " undesirable outputs. The vectors of inputs, desirable outputs and undesirable outputs for each DMU, are given by $\left(x \in R^{j}\right)$, $\left(y^{g} \in R^{e}\right)$, and $\left(y^{b} \in R^{f}\right)$, respectively. The matrices are defined as follows:

$$
\begin{aligned}
& X=\left[x_{1, \ldots, .} x_{n}\right] \epsilon R^{j \times n}, \\
& Y^{g}=\left[y_{1}^{g}, \ldots, y_{n}^{g}\right] \epsilon R^{e \times n}, \\
& Y^{b}=\left[y_{1}^{b}, \ldots, y_{n}^{b}\right] \epsilon R^{f \times n},
\end{aligned}
$$

Assume that all data on $X, Y^{g}$, and $Y^{b}$ are positive. The set (P) as production possibility can be designed as follows,

$P=\left\{\left(x, y^{g}, y^{b}\right) \mid x c a n p r o d u c e\left(y^{g}, y^{b}\right), x \geq X \lambda, y^{g} \leq Y^{g} \lambda, y^{b}=Y^{b} \lambda, \lambda \geq 0\right\}$

where $\lambda$ denotes the positive intensity vector. And the production efficiency and technical efficiency based on the slacks-based directional distance function exhibits variable returns to scale (VRS). This study uses an SBM paradigm that can incorporate 
undesirable outputs into both the objective function and an additional restriction. The SBM-DEA equation set with output-oriented model could be explained in Model 1 below (Lu et al. 2013),

$$
\theta^{*}=\frac{1-\frac{1}{j} \sum_{i=1}^{j} \frac{s_{i}^{-}}{x_{i}}}{1+\frac{1}{e+f}\left(\sum_{r_{1}}^{e}=\frac{s_{r_{1}}^{g}}{y_{r_{1}}^{g}}+\sum_{r_{2}=1}^{f} \frac{s_{r_{2}}^{b}}{y_{r_{2}}^{b}}\right)}
$$

s.t.

$$
\begin{aligned}
& x_{0}=X \lambda+s^{-} \\
& y_{0}^{g}=Y^{g} \lambda-s^{g} \\
& y_{0}^{b}=Y^{b} \lambda+s^{b} \\
& s^{-} \geq 0, s^{g} \geq 0, s^{b} \geq 0, \lambda \geq 0,
\end{aligned}
$$

where $\theta^{*}$ is each DMU's value [0.1]; $i$ is the index of inputs $(1,2 \ldots, \mathrm{m}) ; j$ is the number of inputs; $r_{1}$ is the index of desirable outputs; $r_{2}$ is the index of undesirable outputs; $e$ is the number of desirable outputs; $f$ is the number of undesirable outputs; $s$ is the slack of inputs; $s^{\mathrm{g}}$ is the slack of desirable outputs; and $s^{\mathrm{b}}$ is the slack of undesirable outputs.

The DMU is regarded as being efficient if $\theta^{*}$ is equal to 1 , which means that all the slack values, $s^{-}, s^{g}$, and $s^{b}$ are equal to 0 . If $\theta^{*}$ is less than 1 , then the DMU is considered as out of efficiency, and it could be improved by proper adjusting the ratio of the slacks in inputs and undesirable outputs and augmenting the desirable outputs. But Eq. 2 is not a linear function. As proposed by Tone (2001), a convertible model is used, and the result is seen as:

$$
r^{*}=\min c-\frac{1}{j} \sum_{i=1}^{j} \frac{s_{i}^{-}}{x_{i}}
$$

s.t.

$$
\begin{aligned}
& 1=c+\frac{1}{e+f}\left(\sum_{r_{1}=1}^{e} \frac{s_{r_{1}}^{g}}{y_{r_{1}}^{g}}+\sum_{r_{2}=1}^{f} \frac{s_{r_{2}}^{b}}{y_{r_{2}}^{b}}\right) \\
& x_{0} c=X \varphi+s^{-} \\
& y_{0}^{g} c=Y^{g} \varphi-s^{g} \\
& y_{0}^{b} c=Y^{b} \varphi+s^{b} \\
& s^{-} \geq 0, s^{g} \geq 0, s^{b} \geq 0, \varphi \geq 0, c \geq 0
\end{aligned}
$$

The best solution of the linear program model (Eqs. 10 to 15) can be found, and the optimal solution is found to be $\left(r^{*}, c^{*}, \varphi^{*}, s^{-*}, s^{g *}, s^{b *}\right)$, where $\theta^{*}=r^{*}, \lambda^{*}=\frac{\varphi^{*}}{c^{*}}, s^{-*}=$

$\frac{s^{-*}}{c^{*}}, s^{g *}=\frac{s^{g *}}{c^{*}}, s^{b *}=\frac{s^{b *}}{c^{*}}$ from the linear program model. The solution to $c^{*}, \varphi^{*}, s^{-*}, s^{g *}$ and $s^{b *}$ can be generated through the linear program model with $c^{*} \geq 0$.

\section{Stochastic Frontiers Analysis (SFA)}

SBM-DEA and stochastic frontiers are two alternative methods for estimating frontier functions and thereby measuring the efficiency of production. The input-output slacks are assumed to analyze the initial inefficiency, which is classified as external environmental factors, government regulations, and stochastic interference (Coelli et al. 2005). The traditional SBM-DEA model cannot accurately reflect the optimal adjustment 
on slacks of inputs and outputs which have been influenced by the external environment and random errors on the environmental efficiency evaluation. Different from SBM-DEA software, which involves the use of non-linear programming, SFA involves the use of econometric regression functions (Coelli et al. 1998). The main objective of using the SFA method is to decompose the slack variables into the above external environmental effects by SFA regression, where the slack variables are used to be explained by the environment variables and the mixed error items (Herrala and Goel 2012). The regression equation is as follows:

$$
\begin{aligned}
& S_{i j}=\alpha_{i j}+x_{i} \lambda_{i}=1,2, \cdots \cdots m, j=1,2, \cdots \cdots n \\
& S_{i j}=f^{i}\left(z_{j} ; \beta_{i}\right)+v_{i j}+\mu_{i j}
\end{aligned}
$$

Among the above equations, $S_{i j}$ explains the slack variable of input ${ }_{i}$ or output ${ }_{i}$ of $\mathrm{DMU}_{\mathrm{j}}$, and $\mathrm{z}_{\mathrm{j}}=\left[\mathrm{z}_{1 \mathrm{j}}, \mathrm{z}_{2 \mathrm{j}}, \cdots, \mathrm{z}_{\mathrm{kj}}\right], \beta_{\mathrm{i}}$ explains the external environment parameter to be estimated, $v_{\mathrm{ij}}+\mu_{\mathrm{ij}}$ are comprehensive errors term, where it is supposed that $\nu_{\mathrm{ij}}$ and $\mu_{\mathrm{ij}}$ are independent of each other, and also that they are independent of the k external environment variables. Therefore, the aforementioned SFA regression needs to be designed as follows,

$$
\begin{aligned}
& \gamma=\sigma_{\mu}^{2} /\left(\sigma_{v}^{2}+\sigma_{\mu}^{2}\right) \\
& \sigma^{2}=\sigma_{v}^{2}+\sigma_{\mu}^{2}
\end{aligned}
$$

where $\sigma_{v}^{2}$ and $\sigma_{\mu}^{2}$ explain the variances of the comprehensive error term, and $\gamma$ indicates the ratio of the variance of the inputs and outputs inefficiency to the total variance. When $\gamma$ approaches 1, this indicates that the environmental efficiency of each DMU is different, and the stochastic factor seem small. When $\gamma$ approaches 0 , it indicates that the environmental efficiency difference between the DMUs is not significant and the stochastic difference seems large. Thus, one needs to estimate the parameter by using the maximum likelihood method. The results of each parameter can be estimated and inputs and outputs slack could be adjusted by analyzing its coefficient so that all of the DMUs are taken into consideration for the environmental efficiency.

\section{Data}

To analyze the characteristics of the U.S. pulp and paper industry, the data of 130 facilities were collected from the Environmental Protection Agency (U.S. EPA, 2018)) and FisherSolve databases for 2015 to 2018. The number of facilities was selected based on an optimal collection and data availability of inputs and outputs. These 130 facilities account for $75.83 \%$ of the GHGs emissions (million metric tons) of the pulp and paper industry in the U.S in 2018 (U.S. EPA 2018). Therefore, empirical results derived from these data could substantially reflect the U.S. pulp and paper industry. The models described in Section 3 have been applied to study the environmental efficiency of these 130 facilities.

According to Cooper (1978), the number of DMUs should follow Eq. 20 below. This means that the number of DMUs could be appropriate when it is more than 30 subjects. In this study $(m+p)$ is the sum of input and output variables.

$$
N \geq \max _{\substack{m>0 \\ p>0}}\{5(m+p)\}
$$

The information described in the framework was collected (Table 1). The data on capital and production were obtained from FisherSolve database (FisherSolve, 2015-2018). 
Based on the availability of the data, the inputs for energy (mmBTU) and labor (number of employees) were estimated by using the information of 2019, and adjusting for 20152018 through the change in price of energy (U.S. EPA 2018) and Employment Cost Index respectively (U.S. Bureau of Labor Statistics 2015-2018). The energy use, selected as an input, includes all gas usage and electricity usage from the pulp and paper industry. The official data of GHGs emissions for each facility, selected as undesirable output, are available in the U.S. EPA database as part of the Greenhouse Gas Reporting Program (U.S. EPA 2018), specifically, the Facility Level Information on Greenhouse Gases Tool (FLIGHT), which includes $\mathrm{CO}_{2 \mathrm{eq}}$ from stationary combustion, pulp and paper manufacturing, and industrial waste landfills (Myhre et al. 2013). One advantage of the non-parameter slack measure method is that the desired output of the model not only can be selected as the profit but also as the quantity produced.

Because it would be difficult to present each DMU's result based on each facility throughout the paper, the data were grouped by the states of the U.S., covering 31 states. The average environmental efficiency of each state was estimated based on the environmental efficiency of each facility within the state. Therefore, this study assesses the environmental efficiency of the U.S. pulp and paper industry at a state-level from 2015 to 2018. The data descriptions are presented in Table 1. The degree of variations in all selected variables across each facility from 2015 to 2018 is shown from the standard deviations in Table 2.

Table 1. Input and Output Variables and Data Sources, 2015-2018

\begin{tabular}{|c|c|c|c|}
\hline Indicators & Definition & Unit & Data Source \\
\hline \multirow{3}{*}{ Input } & Capital & Millions USD & \multirow{2}{*}{} \\
\cline { 2 - 3 } & Energy & mmBTU & \multirow{2}{*}{ FisherSolve } \\
\cline { 2 - 3 } & Labor & Employees & \\
\hline Desirable Output & Production & MT & \\
\hline Undesirable Output & GHG emissions $\left(\mathrm{CO}_{2 \mathrm{eq}}\right)$ & MMT & EPA \\
\hline
\end{tabular}

Note: Unit (MT): Metric Tons; Unit (MMT): Million Metric Tons.

Table 2. Descriptive Statistics of Inputs and Outputs, 2015-2018. (N=520)

\begin{tabular}{|c|c|c|c|c|c|c|}
\hline $\begin{array}{c}\text { Inputs \& } \\
\text { Outputs }\end{array}$ & Variable & Unit & Min & Max & Mean & Std.dev. \\
\hline $\begin{array}{c}\text { Non-energy } \\
\text { inputs }\end{array}$ & Capital & $\begin{array}{c}\text { Millions } \\
\text { USD }\end{array}$ & 6.70 & 468.40 & 126.62 & 86.05 \\
\cline { 2 - 7 } & Labor & Employees & 41.19 & $1,435.10$ & 399.19 & 246.98 \\
\hline $\begin{array}{c}\text { Energy } \\
\text { inputs }\end{array}$ & $\begin{array}{c}\text { Energy } \\
\text { Use }\end{array}$ & mmBTU & 182,905 & $26,782,117$ & $5,305,867$ & $4,233,380$ \\
\hline $\begin{array}{c}\text { Desirable } \\
\text { output }\end{array}$ & $\begin{array}{c}\text { Produc- } \\
\text { tion }\end{array}$ & MT & 386,46 & $1,605,349.00$ & $424,086.13$ & 299,592 \\
\hline $\begin{array}{c}\text { Undesirable } \\
\text { output }\end{array}$ & $\mathrm{CO}_{2 \text { eq }}$ & MMT & 0.022 & 1.350 & 0.215 & 0.211 \\
\hline
\end{tabular}




\section{RESULTS AND DISCUSSION}

\section{Environmental Efficiency Assessment}

In terms of environmental efficiency (EE), the performance from 2015 to 2018 of the U.S. pulp and paper industry (PPI) shows that only one state (Vermont) was found to be relatively environmentally efficient with an EE score of 1. The scores from the remaining 30 states, gathered in Table 3, performed inefficiently, ranging from 0.27 to 0.93 .

Table 3. Environmental efficiency of the U.S. PPI

\begin{tabular}{|c|c|c|c|c|c|c|}
\hline State & 2015 & 2016 & 2017 & 2018 & Mean & $\begin{array}{c}\text { Returns to } \\
\text { Scale }\end{array}$ \\
\hline Alabama & 0.578 & 0.591 & 0.656 & 0.633 & 0.614 & Increasing \\
\hline Arkansas & 0.406 & 0.454 & 0.466 & 0.505 & 0.458 & Increasing \\
\hline California & 0.622 & 0.605 & 0.651 & 0.786 & 0.666 & Increasing \\
\hline Connecticut & 0.590 & 0.617 & 0.652 & 0.989 & 0.712 & Increasing \\
\hline Florida & 0.502 & 0.518 & 0.528 & 0.582 & 0.532 & Increasing \\
\hline Georgia & 0.615 & 0.616 & 0.670 & 0.675 & 0.644 & Increasing \\
\hline Idaho & 0.443 & 0.451 & 0.435 & 0.471 & 0.450 & Increasing \\
\hline Indiana & 0.305 & 0.313 & 0.301 & 0.314 & 0.308 & Increasing \\
\hline Kansas & 0.209 & 0.311 & 0.311 & 0.319 & 0.287 & Increasing \\
\hline Kentucky & 0.510 & 0.517 & 0.529 & 0.662 & 0.554 & Increasing \\
\hline Louisiana & 0.586 & 0.614 & 0.682 & 0.761 & 0.661 & Increasing \\
\hline Massachusetts & 0.311 & 0.350 & 0.281 & 0.406 & 0.337 & Increasing \\
\hline Maine & 0.390 & 0.441 & 0.462 & 0.473 & 0.442 & Increasing \\
\hline Michigan & 0.411 & 0.428 & 0.455 & 0.456 & 0.438 & Increasing \\
\hline Minnesota & 0.396 & 0.429 & 0.443 & 0.459 & 0.432 & Increasing \\
\hline Mississippi & 0.896 & 0.901 & 0.964 & 0.956 & 0.929 & Increasing \\
\hline North Carolina & 0.243 & 0.278 & 0.322 & 0.435 & 0.320 & Increasing \\
\hline $\begin{array}{c}\text { New } \\
\text { Hampshire }\end{array}$ & 0.325 & 0.282 & 0.307 & 0.311 & 0.306 & Increasing \\
\hline New York & 0.705 & 0.698 & 0.676 & 0.729 & 0.702 & Increasing \\
\hline Ohio & 0.394 & 0.387 & 0.371 & 0.394 & 0.386 & Increasing \\
\hline Oklahoma & 0.596 & 0.603 & 0.607 & 0.652 & 0.614 & Increasing \\
\hline Oregon & 0.557 & 0.589 & 0.615 & 0.655 & 0.604 & Increasing \\
\hline Pennsylvania & 0.248 & 0.275 & 0.250 & 0.297 & 0.268 & Increasing \\
\hline South Carolina & 0.535 & 0.490 & 0.561 & 0.553 & 0.535 & Increasing \\
\hline Tennessee & 0.365 & 0.445 & 0.436 & 0.482 & 0.432 & Increasing \\
\hline Texas & 0.540 & 0.570 & 0.629 & 0.616 & 0.589 & Increasing \\
\hline Virginia & 0.428 & 0.451 & 0.488 & 0.604 & 0.493 & Increasing \\
\hline Vermont & 1.000 & 1.000 & 1.000 & 1.000 & 1.000 & Constant \\
\hline Washington & 0.388 & 0.421 & 0.468 & 0.430 & 0.427 & Increasing \\
\hline Wisconsin & 0.274 & 0.305 & 0.310 & 0.322 & 0.303 & Increasing \\
\hline West Virginia & 0.292 & 0.310 & 0.354 & 0.361 & 0.329 & Increasing \\
\hline Mean & 0.473 & 0.492 & 0.512 & 0.558 & 0.509 & \\
\hline
\end{tabular}

Specifically, there were 17 states with an environmental efficiency score below 0.5 on average. Thus, there is considerable room for improvement in the environmental efficiency of the PPI. Instead of analyzing the efficiency of the PPI in a purely economic measurement, the environmental efficiency of PPI was assessed including an undesirable output into the SBM-DEA model, so that the contribution of $\mathrm{CO}_{2 \mathrm{eq}}$ emissions to the inefficiency and potential $\mathrm{CO}_{2 \text { eq }}$ reduction could be analyzed (Table 4). These emissions 
are produced during the pulp and paper manufacturing process, fuel combustion, and delivery waste into landfills. Combusting paper products results in emissions of both carbon dioxide $\left(\mathrm{CO}_{2}\right)$ and nitrous oxide $\left(\mathrm{N}_{2} \mathrm{O}\right)$ (U.S. EPA 2016). When paper products are landfilled, anaerobic bacteria can slowly degrade the materials, producing $\mathrm{CH}_{4}$, and $\mathrm{CO}_{2}$ over time (U.S. EPA 2016). The sustainable practice must be implemented by the P\&P Industry from the process of production to landfills. In sum, the U.S. PPI needs improvement in environmental efficiency and sustainable development.

\section{Potential Carbon Equivalents Emission Reduction of PPI}

As the results of Environmental efficiency show, most states are not performing efficiently in the PPI, with the exception of Vermont.

Table 4. Potential $\mathrm{CO}_{2 e q}$ Reduction (MMT)

\begin{tabular}{|c|c|c|c|c|c|}
\hline State & $\mathbf{2 0 1 5}$ & $\mathbf{2 0 1 6}$ & $\mathbf{2 0 1 7}$ & $\mathbf{2 0 1 8}$ & Mean \\
\hline Alabama & $(0.17)$ & $(0.17)$ & $(0.15)$ & $(0.15)$ & $(0.16)$ \\
\hline Arkansas & $(0.18)$ & $(0.17)$ & $(0.17)$ & $(0.17)$ & $(0.17)$ \\
\hline California & $(0.10)$ & $(0.10)$ & $(0.10)$ & $(0.10)$ & $(0.10)$ \\
\hline Connecticut & $(0.05)$ & $(0.05)$ & $(0.05)$ & $(0.01)$ & $(0.04)$ \\
\hline Florida & $(0.19)$ & $(0.18)$ & $(0.16)$ & $(0.14)$ & $(0.17)$ \\
\hline Georgia & $(0.18)$ & $(0.16)$ & $(0.15)$ & $(0.16)$ & $(0.16)$ \\
\hline Idaho & $(0.14)$ & $(0.16)$ & $(0.17)$ & $(0.13)$ & $(0.15)$ \\
\hline Indiana & $(0.03)$ & $(0.03)$ & $(0.03)$ & $(0.03)$ & $(0.03)$ \\
\hline Kansas & $(0.01)$ & $(0.01)$ & $(0.01)$ & $(0.01)$ & $(0.01)$ \\
\hline Kentucky & $(0.05)$ & $(0.04)$ & $(0.04)$ & $(0.03)$ & $(0.04)$ \\
\hline Louisiana & $(0.18)$ & $(0.19)$ & $(0.18)$ & $(0.16)$ & $(0.18)$ \\
\hline Massachusetts & $(0.01)$ & $(0.01)$ & $(0.01)$ & $(0.01)$ & $(0.01)$ \\
\hline Maine & $(0.16)$ & $(0.17)$ & $(0.15)$ & $(0.15)$ & $(0.16)$ \\
\hline Michigan & $(0.10)$ & $(0.10)$ & $(0.11)$ & $(0.11)$ & $(0.10)$ \\
\hline Minnesota & $(0.07)$ & $(0.07)$ & $(0.07)$ & $(0.06)$ & $(0.07)$ \\
\hline Mississippi & $(0.04)$ & $(0.02)$ & $(0.02)$ & $(0.02)$ & $(0.03)$ \\
\hline North Carolina & $(0.09)$ & $(0.09)$ & $(0.08)$ & $(0.07)$ & $(0.08)$ \\
\hline New & $(0.01)$ & $(0.08)$ & $(0.07)$ & $(0.07)$ & $(0.06)$ \\
\hline Hampshire & $(0.06)$ & $(0.06)$ & $(0.07)$ & $(0.03)$ & $(0.06)$ \\
\hline New York & $(0.13)$ & $(0.24)$ & $(0.20)$ & $(0.18)$ & $(0.19)$ \\
\hline Ohio & $(0.12)$ & $(0.12)$ & $(0.13)$ & $(0.13)$ & $(0.12)$ \\
\hline Oklahoma & $(0.07)$ & $(0.07)$ & $(0.08)$ & $(0.07)$ & $(0.07)$ \\
\hline Oregon & $(0.11)$ & $(0.10)$ & $(0.08)$ & $(0.08)$ & $(0.09)$ \\
\hline Pennsylvania & $(0.15)$ & $(0.19)$ & $(0.12)$ & $(0.12)$ & $(0.14)$ \\
\hline South Carolina & $(0.07)$ & $(0.07)$ & $(0.07)$ & $(0.07)$ & $(0.07)$ \\
\hline Tennessee & $(0.08)$ & $(0.08)$ & $(0.08)$ & $(0.09)$ & $(0.08)$ \\
\hline Texas & $(0.24)$ & $(0.24)$ & $(0.23)$ & $(0.24)$ & $(0.24)$ \\
\hline Virginia & 0.00 & 0.00 & 0.00 & 0.00 & 0.00 \\
\hline Vermont & $(0.08)$ & $(0.08)$ & $(0.07)$ & $(0.07)$ & $(0.08)$ \\
\hline Washington & $(0.09)$ & $(0.08)$ & $(0.08)$ & $(0.09)$ \\
\hline Wisconsin & $(0.11)$ & $(0.02)$ & $(0.02)$ & $(0.02)$ & $(0.02)$ \\
\hline West Virginia & $(0.01)$ & & & & \\
\hline & & & & & \\
\hline
\end{tabular}


In Table 4, the average result indicates that the total cumulative growth of $\mathrm{CO}_{2 \mathrm{eq}}$ emissions (31 states) in the PPI should have been reduced by 2.967 MMT to be environmentally efficient, with a range from a minimum $0.01 \mathrm{MMT}$ to a maximum 0.24 MMT by one state from 2015 to 2018 . As a general summary, the findings indicate that $\mathrm{CO}_{2 \text { eq }}$ emissions need to be cut considerably.

Among the 31 states, Virginia showed the most potential for $\mathrm{CO}_{2 \mathrm{eq}}$ emissions cut by $0.24 \mathrm{MMT}$, followed by Ohio with 0.19 MMT and Louisiana with 0.18 MMT. Almost every state had a relatively lower environmental efficiency score and excess of $\mathrm{CO}_{2 \mathrm{eq}}$ emissions, which suggests that a reduction of $\mathrm{CO}_{2 \text { eq }}$ emissions can contribute to the improvement of environmental efficiency in the U.S. PPI. Besides, recycling could reduce $\mathrm{CO}_{2 \text { eq }}$ emissions significantly more than landfilling or combustion (U.S. EPA 2020). However, recycling, as a pathway to reduce GHG emissions, costs significantly more than combustion or landfilling. The state government need to encourage recycling by imposing subsidies and incentive programs on recycling compared to landfilling or combustion.

\section{Analysis of Slack Variables}

From the result of environmental efficiency (EE) scores, all 31 states performed inefficiently with low-efficiency values. Therefore, each state within pulp and paper facilities should seriously consider the slack values of the inputs and outputs each year. The purpose of assessing efficiency and slack value is to achieve the slack value of excess input, while considering undesirable outputs, so that each inefficient DMU can find the optimal implementations and actions in maintaining and operating a sustainable PPI system.

The best target values and the estimated slack values are shown in Table 5. Each slack value with the negative value from Table 5 explains the proportion of potential input and undesirable output cuts for each state from 2015 to 2018. For each state, to achieve an EE score of 1, the capital needs to be cut by the estimated slack value shown in Table 4. Besides, the excess carbon emissions output needs to be reduced by the corresponding slack value. The situation just mentioned does not apply for the highly eco-efficient state, Vermont, which has non-slacks in the capital, energy, and labor input and also has nonexcess in the $\mathrm{CO}_{2 \mathrm{eq}}$ emissions. Among the more environmentally efficient ranked states, the highest-ranked state Mississippi could increase its environmental efficiency growth by $7 \%$ on average per year while cutting its carbon emissions by 0.03 MMT per year and reducing its capital, energy, labor inputs by 22.33 Million USD, $0.52 \mathrm{mmBTU}$ and about 60 employees respectively. For this state, it is estimated that the target value of capital, energy, and labor input and $\mathrm{CO}_{2 \mathrm{eq}}$ emissions that could achieve the optimal environmental efficiency value is 67.07 million USD, $2.29 \mathrm{mmBTU}, 181$ employees, and 0.05 MMT respectively per year. On the other hand, the lowest-ranked state of Pennsylvania should reduce 30.67 million USD, $1.18 \mathrm{mmBTU}$, and about 116 employees, as well as 0.09 MMT of emissions. This shows that Pennsylvania has more than $73.2 \%$ needs for improvement until its environmental efficiency score reaches a peak value. Comparing the findings from Tables 3 to 5, the excess capital, energy, and labor input, and potential $\mathrm{CO}_{2 \mathrm{eq}}$ emissions output had an inhibiting effect on environmental efficiency in the U.S. PPI. Achieving a balance between adequate pulp and paper production provisions and reducing GHGs emissions has been a challenging task. The slack results show that the environmental efficiency performances in the PPI through each through each facility's environmental efficient allocation of inputs and sustainable practices on the reduction of $\mathrm{CO}_{2 \mathrm{eq}}$ emissions can be potentially improved. 
Table 5. Summary of Average Excess in Inputs and Shortfall in Outputs, 20152018 (31 States)

\begin{tabular}{|c|c|c|c|c|c|c|c|c|c|}
\hline \multirow{3}{*}{ State } & \multicolumn{6}{|c|}{ Input Excess } & \multicolumn{2}{|c|}{$\begin{array}{c}\text { Undesirable } \\
\text { Outputs } \\
\text { (Excess) }\end{array}$} & \multirow{3}{*}{\begin{tabular}{|c|}
$\begin{array}{c}\text { Desirable } \\
\text { Outputs } \\
\text { (Shortfalls) }\end{array}$ \\
$\begin{array}{c}\text { Production } \\
\text { (MT) }\end{array}$ \\
$\begin{array}{c}\text { Slack } \\
\text { (Percen- } \\
\text { tage) }\end{array}$ \\
\end{tabular}} \\
\hline & \multicolumn{2}{|c|}{$\begin{array}{c}\text { Capital } \\
\text { (Millions USD) }\end{array}$} & \multicolumn{2}{|c|}{$\begin{array}{c}\text { Energy } \\
\text { (mmBTU) }\end{array}$} & \multicolumn{2}{|c|}{$\begin{array}{c}\text { Labor } \\
\text { (Employees) }\end{array}$} & \multicolumn{2}{|c|}{$\begin{array}{c}\mathrm{CO}_{2} \mathrm{eq} \text { (Million } \\
\text { MT) }\end{array}$} & \\
\hline & \begin{tabular}{|c|} 
Slack \\
(Percent \\
age)
\end{tabular} & \begin{tabular}{|l|} 
Target \\
Value
\end{tabular} & $\begin{array}{c}\text { Slack } \\
\text { (Percen } \\
\text { tage) }\end{array}$ & $\begin{array}{l}\text { Target } \\
\text { Value }\end{array}$ & $\begin{array}{c}\text { Slack } \\
\text { (Percen } \\
\text { tage) }\end{array}$ & $\begin{array}{l}\text { Target } \\
\text { Value }\end{array}$ & $\begin{array}{c}\text { Slack } \\
\text { (Percent } \\
\text { age) }\end{array}$ & $\begin{array}{l}\text { Target } \\
\text { Value }\end{array}$ & \\
\hline Alabama & $-37.08 \%$ & 49.77 & $-24.86 \%$ & 2.31 & $-33.63 \%$ & 136.06 & $-55.22 \%$ & 0.01 & $0 \%$ \\
\hline Arkansas & $-39.23 \%$ & 36.94 & $-42.53 \%$ & 1.26 & $-36.31 \%$ & 114.84 & $-55.92 \%$ & 0.01 & $0 \%$ \\
\hline California & $-46.27 \%$ & 8.96 & $-21.57 \%$ & 0.96 & $-17.40 \%$ & 59.19 & $-56.50 \%$ & 0.01 & $0 \%$ \\
\hline Connecticut & $-45.26 \%$ & 9.08 & $-8.36 \%$ & 0.99 & $-13.67 \%$ & 54.77 & $-44.51 \%$ & 0.01 & $0 \%$ \\
\hline Florida & $-40.98 \%$ & 34.04 & $-36.62 \%$ & 2.34 & $-34.38 \%$ & 111.28 & $-55.13 \%$ & 0.01 & $0 \%$ \\
\hline Georgia & $-33.10 \%$ & 44.51 & $-30.01 \%$ & 2.39 & $-34.95 \%$ & 132.68 & $-52.79 \%$ & 0.02 & $0 \%$ \\
\hline Idaho & $-37.27 \%$ & 67.21 & $-28.87 \%$ & 2.52 & $-40.95 \%$ & 163.55 & $-53.65 \%$ & 0.02 & $0 \%$ \\
\hline Indiana & $-51.11 \%$ & 3.82 & $-47.77 \%$ & 0.25 & $-40.95 \%$ & 42.84 & $-50.76 \%$ & 0.01 & $0 \%$ \\
\hline Kansas & $-52.26 \%$ & 1.68 & $-48.81 \%$ & 0.17 & $-39.20 \%$ & 28.45 & $-48.56 \%$ & 0.01 & $0 \%$ \\
\hline Kentucky & $-45.57 \%$ & 34.25 & $-34.20 \%$ & 0.89 & $-23.97 \%$ & 89.23 & $-48.31 \%$ & 0.01 & $0 \%$ \\
\hline Louisiana & $-28.83 \%$ & 64.29 & $-25.37 \%$ & 3.53 & $-31.54 \%$ & 149.10 & $-54.12 \%$ & 0.02 & $0 \%$ \\
\hline $\begin{array}{c}\text { Massachusett } \\
\text { s }\end{array}$ & $-50.66 \%$ & 13.58 & -38 & 1.60 & $35 \%$ & 77.21 & $-36.96 \%$ & 0.01 & $0 \%$ \\
\hline Maine & $-47.84 \%$ & 28.52 & $-34.79 \%$ & 1.89 & $-40.29 \%$ & 97.63 & $-56.18 \%$ & 0.01 & $0 \%$ \\
\hline Michigan & $-47.98 \%$ & 17.09 & $-30.91 \%$ & 1.68 & $-39.64 \%$ & 75.97 & $-55.91 \%$ & 0.01 & $0 \%$ \\
\hline Minnesota & $-43.43 \%$ & 34.72 & $-35.00 \%$ & 1.31 & $-38.96 \%$ & \begin{tabular}{|l|}
113.99 \\
\end{tabular} & $-50.63 \%$ & 0.01 & $0 \%$ \\
\hline Mississippi & $-13.63 \%$ & 67.07 & $-11.10 \%$ & 2.46 & $-14.85 \%$ & \begin{tabular}{|l|}
182.67 \\
\end{tabular} & $-22.19 \%$ & 0.05 & $0 \%$ \\
\hline North Carolina & $-53.15 \%$ & 6.95 & $-35.75 \%$ & 0.60 & $-44.25 \%$ & 41.85 & $-54.94 \%$ & 0.01 & $0 \%$ \\
\hline $\begin{array}{c}\text { New } \\
\text { Hampshire }\end{array}$ & $-49.87 \%$ & 9.40 & $-41.91 \%$ & 0.98 & $-46.88 \%$ & 60.40 & $-53.78 \%$ & 0.01 & $0 \%$ \\
\hline New York & $-31.30 \%$ & 52.16 & $-17.69 \%$ & 1.32 & $-20.48 \%$ & 154.06 & $-41.70 \%$ & 0.02 & $0 \%$ \\
\hline Ohio & $-47.49 \%$ & 10.84 & $-44.71 \%$ & 0.44 & $-41.67 \%$ & 62.43 & $-57.78 \%$ & 0.01 & $0 \%$ \\
\hline Oklahoma & $-30.15 \%$ & 97.68 & $-3.42 \%$ & 3.90 & $-4.05 \%$ & 145.12 & $-54.16 \%$ & 0.01 & $0 \%$ \\
\hline Oregon & $-49.98 \%$ & 22.81 & $-21.22 \%$ & 1.85 & $-27.12 \%$ & 84.94 & $-53.84 \%$ & 0.01 & $0 \%$ \\
\hline Pennsylvania & $-54.07 \%$ & 4.86 & $-41.56 \%$ & 0.52 & $-45.80 \%$ & 35.91 & $-57.59 \%$ & 0.01 & $0 \%$ \\
\hline South Carolina & $-41.90 \%$ & 31.06 & $-25.91 \%$ & 2.80 & $-40.67 \%$ & \begin{tabular}{|l|}
110.79 \\
\end{tabular} & $-56.03 \%$ & 0.01 & $0 \%$ \\
\hline Tennessee & $-51.42 \%$ & 18.73 & $-36.75 \%$ & 1.21 & $-36.74 \%$ & 72.00 & \begin{tabular}{|l|}
$-54.18 \%$ \\
\end{tabular} & 0.01 & $0 \%$ \\
\hline Texas & $-42.69 \%$ & 23.09 & $-22.82 \%$ & 1.92 & $-37.05 \%$ & 89.20 & $-54.15 \%$ & 0.01 & $0 \%$ \\
\hline Virginia & $-43.77 \%$ & 22.14 & $-27.68 \%$ & 1.60 & $-37.07 \%$ & 98.70 & $-58.27 \%$ & 0.01 & $0 \%$ \\
\hline Vermont & $0.00 \%$ & 118.28 & $0.00 \%$ & 1.90 & $0.00 \%$ & 315.61 & $0.00 \%$ & 0.02 & $0 \%$ \\
\hline Washington & $-47.72 \%$ & 16.70 & $-40.04 \%$ & 0.77 & $-38.95 \%$ & 78.49 & \begin{tabular}{|l|}
$-53.66 \%$ \\
\end{tabular} & 0.01 & $0 \%$ \\
\hline Wisconsin & $-54.08 \%$ & 5.07 & $-45.10 \%$ & 0.36 & $-45.73 \%$ & 39.87 & $-57.15 \%$ & 0.00 & $0 \%$ \\
\hline West Virginia & $-52.28 \%$ & 10.50 & $-42.82 \%$ & 1.27 & $-41.58 \%$ & 53.37 & $-45.87 \%$ & 0.01 & $0 \%$ \\
\hline
\end{tabular}

For further analysis, this study analyzes specific Pulp and Paper facilities within two states above with environmental efficiency ratings from the highest (Mississippi) to lowest (Pennsylvania). In Mississippi, it was shown that Georgia Pacific contributes the most shares to the state's optimal environmental efficiency. Georgia Pacific Company has 
been focusing on sustainable practice, not only on the economic stability of the company but also on protecting environmental resources to minimize GHG emissions (GeorgiaPacific 2018). G-P LLC plans to estimate that approximately $\$ 80$ million sustainability investments will be invested to help the mill to reduce nitrous oxide emissions by 67 percent (Georgia-Pacific 2020).

Two other mills, International Paper's Columbus Mill and Vicksburg Mill, have not been as efficient as Georgia Pacific (Monticello) in terms of the allocation and utilization of capital, labor, and energy. However, the International Paper mills had less (0.01 and 0.02) slack of $\mathrm{CO}_{2}$ eq MMT, respectively, while G-P had excess $\mathrm{CO}_{2} \mathrm{eq}$ at 0.11 MMT from 2015-2018 due to the different size of mills.

Table 6. Summary of Average Excess in Inputs and Shortfall in Outputs, 20152018 (Representative Facilities)

\begin{tabular}{|c|c|c|c|c|c|c|}
\hline \multirow{3}{*}{ State } & & \multicolumn{3}{|c|}{ Input Excess } & \multirow{2}{*}{\begin{tabular}{|c|}
$\begin{array}{c}\text { Undesirable } \\
\text { Outputs } \\
\text { (Excess) }\end{array}$ \\
$\begin{array}{c}\mathrm{CO}_{2} \mathrm{eq} \\
\text { (Million MT) }\end{array}$ \\
\end{tabular}} & \multirow{2}{*}{\begin{tabular}{|c|}
$\begin{array}{c}\text { Desirable } \\
\text { Outputs } \\
\text { (Shortfalls) }\end{array}$ \\
$\begin{array}{c}\text { Production } \\
\text { (MT) }\end{array}$
\end{tabular}} \\
\hline & & $\begin{array}{l}\text { Capital } \\
\text { (Millions } \\
\text { USD) }\end{array}$ & $\begin{array}{c}\text { Energy } \\
\text { (mmBTU) }\end{array}$ & $\begin{array}{c}\text { Labor } \\
\text { (Employees) }\end{array}$ & & \\
\hline & & Slack & Slack & Slack & Slack & Slack \\
\hline \multirow{3}{*}{ Mississippi } & $\begin{array}{l}\text { GEORGIA PACIFIC } \\
\text { MONTICELLO LLC }\end{array}$ & 0.00 & 0.00 & 0.00 & 0.00 & 0.00 \\
\hline & $\begin{array}{c}\text { INTERNATIONAL PAPER } \\
\text { - COLUMBUS MILL } \\
\end{array}$ & -38.16 & -1.56 & -109.2 & -0.06 & 0.00 \\
\hline & \begin{tabular}{|} 
INTERNATIONAL PAPER \\
-VICKSBURG MILL \\
\end{tabular} & -28.82 & -0.57 & -88.95 & -0.01 & 0.00 \\
\hline \multirow{6}{*}{ Pennsylvania } & \begin{tabular}{|c|} 
CASCADES TISSUE \\
GROUP PA RANSOM PLT \\
\end{tabular} & -10.96 & -0.84 & -43.06 & -0.01 & 0.00 \\
\hline & $\begin{array}{l}\text { DOMTAR PAPER } \\
\text { COMPANY, LLC }\end{array}$ & -62.98 & -0.92 & -157.4 & -0.17 & 0.00 \\
\hline & NGC INDUSTRIES INC & -12.71 & -0.67 & -29.73 & -0.02 & 0.00 \\
\hline & NEWMAN \& CO & -6.90 & -0.29 & -64.70 & -0.02 & 0.00 \\
\hline & PIXELLE SPECIALTY LLC & -15.79 & -1.56 & -44.69 & -0.32 & 0.00 \\
\hline & \begin{tabular}{|c|} 
WESTROCK LLC- \\
STROUDSBURGE MILL
\end{tabular} & -74.50 & -2.78 & -355.2 & -0.01 & 0.00 \\
\hline
\end{tabular}

In Pennsylvania, input and output slack results of six mills have been reported in Table 6. The reason for the lowest environmental efficiency ranking of the State is mainly due to which five of the six mills, including Cascades, Domtar, NGC, Pixelle, and West Rock, have not been equipped with high efficiency in the usage of capital, energy, and labor, resulting in the slack of resources, making it difficult to achieve the dual goals of the economy and environmental protection.

It is undeniable that some facilities have been doing a good job in protecting our environment, resulting in less $\mathrm{CO}_{2}$ eq redundancy at range from 0.01 to $0.02 \mathrm{MMT}$ from 2015 to 2018, such as WestRock, it business strategy has been in connection with matters relating to environmental compliance (WestRock 2016, 2019). Based on these results, it can be concluded that for the sustainable development of PPI, more attention needs to be paid to environmental practices as well as efficient allocation of labor, energy, capital, and other resources in the production process. 


\section{The Influence of External Environmental Factors on the Slack of Input and Unexpected Output}

Table 7. Stochastic Frontier Analysis (SFA) Regression Results

\begin{tabular}{|c|c|c|c|c|c|c|c|c|}
\hline & \multicolumn{2}{|c|}{ Capital Slack } & \multicolumn{2}{|c|}{ Energy Slack } & \multicolumn{2}{|c|}{ Labor Slack } & \multicolumn{2}{|c|}{$\mathrm{CO}_{2 \mathrm{e}}$ Slack } \\
\hline & Coef. & $\begin{array}{c}\text { t-value } \\
\text { test }\end{array}$ & Coef. & $\begin{array}{c}\text { t-value } \\
\text { test }\end{array}$ & Coef. & $\begin{array}{c}\text { t-value } \\
\text { test }\end{array}$ & Coef. & $\begin{array}{c}\text { t-value } \\
\text { test }\end{array}$ \\
\hline $\begin{array}{c}\text { Industrial Waste } \\
\text { Landfill }\end{array}$ & 0.61 & $44.12^{\star \star \star}$ & 0.54 & $1.45^{*}$ & 0.61 & $23.00^{* * \star}$ & 0.38 & $1.26^{*}$ \\
\hline $\begin{array}{c}\text { Wastewater } \\
\text { Treatment }\end{array}$ & -0.28 & $2.31^{\star \star \star}$ & -0.28 & $0.91^{*}$ & -0.13 & $8.03^{\star \star \star}$ & -0.31 & $-1.29^{*}$ \\
\hline $\begin{array}{l}\text { Solid Waste } \\
\text { Combustion }\end{array}$ & 0.15 & 0.56 & 0.04 & 0.20 & 0.25 & $2.80^{\star \star \star}$ & -0.21 & $-0.99^{*}$ \\
\hline Constant & 1.92 & $29.34^{\star \star \star}$ & 0.55 & $3.14^{* * *}$ & 2.33 & $1.93^{\star \star \star}$ & -1.18 & $-2.14^{* \star *}$ \\
\hline Sigma-squared & \multicolumn{2}{|c|}{$0.24^{* * *}$} & \multicolumn{2}{|c|}{$0.22^{* * *}$} & \multicolumn{2}{|c|}{$0.34^{* \star *}$} & \multicolumn{2}{|c|}{$0.13^{* * *}$} \\
\hline Gamma & \multicolumn{2}{|c|}{0.983} & \multicolumn{2}{|c|}{0.962} & \multicolumn{2}{|c|}{0.991} & \multicolumn{2}{|c|}{0.989} \\
\hline Log likelihood & \multicolumn{2}{|c|}{-141.49} & \multicolumn{2}{|c|}{-39.98} & \multicolumn{2}{|c|}{-176.82} & \multicolumn{2}{|c|}{-46.85} \\
\hline $\begin{array}{l}\text { LR Test of the } \\
\text { one-side Error }\end{array}$ & \multicolumn{2}{|c|}{$19.82^{* \star *}$} & \multicolumn{2}{|c|}{$8.74^{* \star *}$} & \multicolumn{2}{|c|}{$21.71^{* \star *}$} & \multicolumn{2}{|c|}{$6.38^{* * *}$} \\
\hline
\end{tabular}

Note: $* \mathrm{p}<0.1 ; * * \mathrm{p}<0.05 ; * * * \mathrm{p}<0.01$ The values in parentheses are the corresponding estimated T-statistics.

Through the calculation of the SBM-DEA model (Table 5), it was found that the slack on production output of each state was estimated as having a 0 value, and all inputs and the undesired output $\mathrm{CO}_{2}$ eq emissions had a certain degree of slack, indicating that insufficient production in the production process is not a contributor to environmental inefficient in the U.S. PPI. In addition, the main reasons for the loss of environmental efficiency are contributed by the capital, energy, labor input, and $\mathrm{CO}_{2}$ eq emissions. By applying Frontier 4.1 software, a regression analysis was carried out on all inputs and undesirable outputs. The results are shown in Table 7. The gamma value was greater than 0.95, indicating that proposing SFA was reasonable in this study, and the likelihood ratio (LR) test results of 19.82, 8.47, 21.71, and 6.38 were located outside of the $99 \%$ confidence interval, explaining that external environment inefficiency was present. The slack of inputs and $\mathrm{CO}_{2}$ eq output could be reduced by cutting external environmental variables. And, if external environmental variables are negatively correlated with inputs and $\mathrm{CO}_{2} \mathrm{eq}$ emissions, it indicates that the increase of external environmental variables will reduce the slack amount of the input and undesirable output variable. In other words, the external environmental factor will be conducive to the environmental efficiency of U.S. PPI and vice versa.

In this study, external environmental variables were selected from the amount of Industrial Waste Landfills, Wastewater Treatment Plants, and Solid Waste Combustion of each state which represent variables of IWL, WWT, and SWC, respectively (U.S. EPA, 2018). From the table, firstly it can be seen that the amount of Industrial Landfills is significantly positively correlated with the slack value of capital, energy, labor input, and $\mathrm{CO}_{2}$ eq emissions. This shows that the larger the number of industrial waste landfills in each state, the larger the scale of IWL, which may indirectly lead to inefficient use and distribution of capital, energy, and labor, and also contribute to increasing $\mathrm{CO}_{2} \mathrm{eq}$ emissions. This result indicated that the loss of the environmental efficiency of the U.S. PPI. (U.S. EPA 2018). Secondly, the variable of wastewater treatment is significantly 
negatively correlated with the slack value of capital, energy, labor input, and $\mathrm{CO}_{2} \mathrm{eq}$ emissions. This result showed that wastewater treatment plants (WWTPs) have been widely applied to the P\&P industry, and supplementary treatments have positive effects on the cost-effective inputs of capital, labor, and energy in the PPI. The P\&P industry has been a big contributor to the usage of water as process water (Savant et al. 2006; Hubbe et al. 2016). Although traditional WWTPs may generate nitrogen due to chemical and energy use (Bani Shahabadi et al. 2009), more advanced treatment, such as anaerobic wastewater treatment can be used to convert extra $\mathrm{CO}_{2}$ eq to methane as fuels in other places which can help reduce $\mathrm{CO}_{2}$ eq emissions and energy input (Sanusi and Menzes 2014; Meyer and Edwards 2014). These results also showed that WWTPs are currently focusing on environmental efficiency using environmentally friendly treatment methods instead of the traditional one to decrease $\mathrm{CO}_{2}$ eq emissions for the PPI. Therefore, the more advanced WWTPs in a state, the more optimized wastewater treatments could provide those pulp and paper mills with producing more sustainable and environmental products. Thirdly, the variable of solid waste combustion is positively correlated with the slack of capital, energy, and labor input, but has no significant impact on capital and energy slack. This shows that the waste-paper treatment methods of the PPI mainly include recycling, combustion, and landfills. With the implementation of the National Sword Policy, China banned imports of solid waste including recovered papers by the end of 2017 (Paben 2017). Consequently, the U.S. MRFs have suspended the recycling of solid wastes, and the available treatments of solid waste were largely chosen as combustion and landfill (Staub 2017). The regression result shows that due to the larger the scale of solid waste combustion, it may adversely affect the effective use of capital, energy, and labor, and ultimately lead to the ecological inefficiency of the PPI. However, the variable is significantly negatively correlated with the relaxation value of $\mathrm{CO}_{2}$ eq emissions. This may be dependent on whether the $\mathrm{CO}_{2} \mathrm{eq}$ emissions estimated in this study were mainly collected from the PPI manufacturing, combustion, and landfill. The combustion could reduce GHG emissions by transforming methane to carbon dioxide. And the combusted residue could be used as agricultural fertilizers (US EPA 2020).

\section{CONCLUSIONS}

1. Based on the analysis, 31 states had an average environmental efficiency (EE) score of 0.509 from 2015 to 2018 , indicating that these states considerably have a potential room for improvements of environmental efficiency and have the potential to reduce $\mathrm{CO}_{2 \mathrm{eq}}$ emissions and inputs. And for the $\mathrm{CO}_{2 \text { eq }}$ potential reduction analysis, the estimation results showed that the U.S. Pulp and Paper Industry (PPI) had a large potential range to cut the excess $\mathrm{CO}_{2 \text { eq }}$ emissions, with a wide range from a minimum 0.01 MMT to a maximum of 0.24 MMT from 2015 to 2018 in the U.S. PPI. Therefore, P\&P facilities need to implement more sustainable practices from the process of production to landfills. Also, recycling was shown to be a promising pathway to minimizing greenhouse gas (GHG) emissions. This indicates that state governments should encourage recycling by imposing less tax on recycling compared to landfilling or combustion.

2. When assessing the slacks of inputs and outputs by using a non-radial slacks-based measure - data envelopment analysis (SBM-DEA) model, the result of excess inputs and undesirable output can explain that each state has responsibility for the cutting of excess 
capital, energy and labor input cost, respectively, by the estimated input slacks. In addition, the excess carbon equivalents emissions output needs to be reduced. The slack results indicates that environmental efficiency performances in the PPI through each facility's environmental efficient allocation of inputs and sustainable practices on the reduction of $\mathrm{CO}_{2 \mathrm{eq}}$ could be potentially improved.

3. In terms of the differentiated performance of the environmental efficiency of the PPI in each state, each U.S. state's government and relevant environmental authorities are promoting sustainable industrial development and implementing active ecological incentive policies. It is necessary to take into account the difference both on quantity and quality of industrial waste landfills, wastewater treatment, and solid waste combustion in each state and put forward target requirements that match each state's developmental stage and waste management capability. Also, more attention needs to be paid to the issue of environmental efficiency in the development of the PPI and improve the environmental efficiency of the U.S. PPI.

\section{ACKNOWLEDGMENTS}

The work was financially supported by the Jiangxi Province Graduate Student Innovation Program (Jiangxi, China, No. YC2019-B071). Thanks are due to FisherSolve for valuable assistant. We greatly thank NCSU for the valuable opportunity to learn. We also appreciate the anonymous reviewers for their valuable comments on an earlier draft of our paper.

\section{REFERENCES CITED}

Aigner, D., Lovell, C. A. K., and Schmidt, P. (1977). "Formulation and estimation of stochastic frontier production function models," Journal of Econometrics, 6(1), 2137. DOI: 10.1016/0304-4076(77)90052-5.

Ashrafi, O., Yerushalmi, L. and Haghighat, F. (2013). "Greenhouse gas emission by wastewater treatment plants of the pulp and paper industry - Modeling and simulation," International Journal of Greenhouse Gas Control. 17, 462-472. DOI: 10.1016/j.ijggc.2013.06.006.

Bani Shahabadi, M., Yerushalmi, L. and Haghighat, F. (2009). "Impact of process design on greenhouse gas (GHG) generation by wastewater treatment plants," Water Research. 43(10), 2679-2687. DOI: 10.1016/j.watres.2009.02.040

Carvalho, A., Mimoso, A. F., Mendes, A. N., and Matos, H. A. (2014). "From a literature review to a framework for environmental process impact assessment index," Journal of Cleaner Production 64, 36-62. DOI: 10.1016/j.jclepro.2013.08.010

Charnes, A., Cooper, W. W., and Rhodes, E. (1978). "Measuring the efficiency of decision making units," Eur. J. Oper. Res. 2(6), 429-444. DOI: 10.1016/03772217(78)90138-8

Chang, Y.-T., Zhang N., Danao D., and Zhang N. (2013). "Environmental efficiency analysis of transportation system in China: A non-radial DEA approach," Energy Policy 58, 277-283. DOI: 10.1016/j.enpol.2013.03.011

Chang Y.-T., Park, H.-s., Jeong, J.-b., and Lee, J.-w. (2014). "Evaluating economic and 
environmental efficiency of global airlines: A SBM-DEA approach," Transp. Res. Part D: Transp. Environ. 27, 46-50. DOI: 10.1016/j.trd.2013.12.013

Chen, J., Song, M., and Xu, L. (2015). "Evaluation of environmental efficiency in China using data envelopment analysis," Ecol. Indic. 52, 577-583. DOI:

10.1016/j.ecolind.2014.05.008

Chen, L., and Jia, G. (2017). "Environmental efficiency analysis of China's regional industry: A data envelopment analysis (DEA) based approach," Journal of Cleaner Production 142, 846-853. DOI: 10.1016/j.jclepro.2016.01.045

Climate Action (2019). "Climate Change - Summit," United Nations, Retrieved from (http://www.un.org/en/climatechange/faq.shtml), Accessed October, 2019

Coelli, T. J., Rao, D. S. P., O’Donnell, C. J., and Battese, G. E. (2005). "Additional topics on stochastic frontier analysis," in: An Introduction to Efficiency and Productivity Analysis," Springer, US, pp. 263-288. DOI: 10.1007/0-387-25895-7_10

Coelli, T., Rao, D. S. P., and Battese, G. E. (1998). "Efficiency measurement using stochastic frontiers," in: An Introduction to Efficiency and Productivity Analysis," Springer, US, pp. 183-198. DOI: 10.1007/978-1-4615-5493-6_8

Cook, W. D., Liang, L., and Zhu, J. (2010). "Measuring performance of two-stage network structures by DEA: A review and future perspective," ACS Omega 38(6), 423-430. DOI: 10.1016/j.omega.2009.12.001

Färe, R., and Grosskopf, S. (2004). "Modeling undesirable factors in efficiency evaluation: Comment," European Journal of Operational Research 157(1), 242-245. DOI:10.1016/S0377-2217(03)00191-7

Georgia-Pacific (2018). "Sustainable practice in Georgia Pacific," Retrieved from (https://www.gp.com/sustainability), Accessed August, 2020

Georgia-Pacific (2020). "Update: A change of scenery at Green Bay Broadway," Retrieved from (https://www.gp.com/news/2020/02/change-of-scenery-green-bay), Accessed August, 2020

Guo, X., Zhu, L., Fan, Y., and Xie, B. (2011). "Evaluation of potential reductions in carbon emissions in Chinese provinces based on environmental DEA," Energy Policy 39, 2352-2360. DOI: 10.1016/j.enpol.2011.01.055

Hawkins, T. R., Singh, B., Majeau-Bettez, G. S., and Hammer, A. (2013). "Comparative environmental life cycle assessment of conventional and electric vehicles'," Journal of Industrial Ecology 17(1), 53-64. DOI: 10.1111/j.1530-9290.2012.00532.x

He, F., Zhang, Q., Lei, J., Fu, W., and Xu, X. (2013). "Energy efficiency and productivity change of China"s iron and steel industry: Accounting for undesirable outputs," Energy Policy 54, 204-213. DOI: 10.1016/j.enpol.2012.11.020

Herrala, R., and Goel, R. K. (2012). "Global $\mathrm{CO}_{2}$ efficiency: Country-wise estimates using a stochastic cost frontier," Energy Policy, 45, 762-770. DOI:

10.1016/j.enpol.2012.03.007

Hong, L., and Shi, J. F. (2014). "Energy efficiency analysis on Chinese industrial sectors: An improved Super-SBM model with undesirable outputs," J. Clean Prod. 65(4), 97 107. DOI: 10.1016/j.jclepro.2013.09.035

Hubbe, M. A., Metts, J. R., Hermosilla, D., Blanco, M. A., Yerushalmi, L., Haghighat, F., Lindholm-Lehto, P., Khodaparast, Z., Kamali, M., and Elliott, A. (2016).

"Wastewater treatment and reclamation: A review of pulp and paper industry practices and opportunities," BioResources 11(3), 7953-8091.

DOI 10.15376/biores.11.3. Hubbe

Kortelainen, M. (2008). "Dynamic environmental performance analysis: A Malmquist 
index approach," Ecological Economics 64(4), 701-715. DOI:

10.1016/j.ecolecon.2007.08.001

Lee, T., Yeo, G.-T. and Thai, V. V (2014). "Environmental efficiency analysis of port cities: Slacks-based measure data envelopment analysis approach," Transport Policy, 33, 82-88. DOI: 10.1016/j.tranpol.2014.02.009

Li, Y., Shi, X., and Emrouznejad, A. (2018). "Environmental performance evaluation of Chinese industrial systems: A network SBM approach," Journal of the Operational Research Society 69(6), 825-839. DOI: 10.1057/s41274-017-0257-9

Lozano, S., Iribarren, D., Moreira, M. T., and Feijoo, G. (2010). "Environmental impact efficiency in mussel cultivation," Resources, Conservation and Recycling 54(12), 1269-1277. DOI: 10.1016/j.resconrec.2010.04.004

Lu, C. C., Chiu, Y. H., Shyu, M. K, and Lee, J. H. (2013). "Measuring $\mathrm{CO}_{2}$ emission efficiency in OECD countries: Application of the hybrid efficiency model," Econ. Model 32, 130-135. DOI: 10.1016/j.econmod.2013.01.047

Meyer, T., and Edwards, E. A. (2014). "Anaerobic digestion of pulp and paper mill wastewater and sludge," Water Research 65, 321-349. DOI: 10.1016/j.watres.2014.07.022

Miettinen, P., and Hämäläinen, R. P. (1997). "How to benefit from decision analysis in environmental life cycle assessment (LCA)," European Journal of Operational Research 102(2), 279-294. DOI: 10.1016/S0377-2217(97)00109-4

Myhre, G., Shindell, D., Bréon, F.-M., Collins, W., Fuglestvedt, J., Huang, J., Koch, D., Lamarque, J.-F., Lee, D., Mendoza, B., et al. (2013). "Anthropogenic and natural radiative forcing," in: Climate Change 2013: The Physical Science Basis. Contribution of Working Group I to the Fifth Assessment Report of the Intergovernmental Panel on Climate Change, Cambridge University Press, Cambridge, UK, pp. 659-740.

Olander, S. (2012). "Life cycle assessment in the built environment," Construction Management and Economics 30(7), 594-596. DOI: 10.1080/01446193.2012.673727

Önüt, S., and Soner, S. (2006). "Energy efficiency assessment for the Antalya Region hotels in Turkey," Energy and Buildings 38(8), 964-971. DOI: 10.1016/j.enbuild.2005.11.006

Paben, J. (2017). “China announces 'Sword' crackdown on illegal recyclable material imports," Retrieved from (https://resource-recycling.com/recycling/2017/02/21/chinaannounces-sword-crackdown-illegal-recyclable-material-imports/), Accessed Feb., 2020

Park, Y. S., Lim, Siew H., Egilmez, G., and Szmerekovsky, J. (2016). "Environmental efficiency assessment of U.S. transport sector: A slack-based data envelopment analysis approach," Transportation Research Part D: Transport and Environment 61(2018), 152-164. DOI: 10.1016/j.trd.2016.09.009

Pastor, J. T., Ruiz, J. L., and Sirvent, I. (1999). "An enhanced DEA Russell graph efficiency measure,” European Journal of Operational Research 115(3), 596-607. DOI: $10.1016 / \mathrm{S} 0377-2217(98) 00098-8$

Poeschl, M., Ward, S., and Owende, P. (2012). "Environmental impacts of biogas deployment - Part II: life cycle assessment of multiple production and utilization pathways," Journal of Cleaner Production 24, 184-201.

DOI:10.1016/j.jclepro.2011.10.030

Ramanathan, R. (2005). "Estimating energy consumption of transport modes in India using DEA and application to energy and environmental policy," Journal of the 
Operational Research Society 56(6), 732-737. DOI: 10.1057/palgrave.jors.2601866

Sanusi, O., and Menezes, G. B. (2014). "Pulp and paper mill effluents management," Water Environment Research 86(10), 1535-1544. DOI:

$10.2175 / 106143014 \times 14031280668137$

Savant, D. V., Abdul-Rahman, R., and Ranade, D. R. (2006). "Anaerobic degradation of adsorbable organic halides (AOX) from pulp and paper industry wastewater," Bioresource Technology, 97(9), 1092-1104. DOI: 10.1016/j.biortech.2004.12.013U. S. Environmental Protection Agency (EPA) (2017). "Understanding global warming potentials" Retrieved from (http://www.epa.gov/ghgemissions/understanding-globalwarming-potentials), Accessed December, 2019

Shephard, R. W. (1970). "Theory of cost and production functions," Princeton University Press, Princeton, NJ, USA.

Shi, G. M., Bi, J., and Wang, J. (2010). "Chinese regional industrial energy efficiency evaluation based on a DEA model of fixing non-energy inputs," Energy Policy 38, 6172-6179. DOI: 10.1016/j.enpol.2010.06.003

Staub, C. (2017). "Local programs feel the 'dire' effects of China's ban," Retrieved from (https://resource-recycling.com/recycling/2017/10/03/local-programs-feel-direeffects-chinas-ban/). Accessed January 2020

Tone, K. (2001). "A slacks-based measure of efficiency in data envelopment analysis," Eur. J. Oper. Res. 130, 498-509. DOI: 10.1016/S0377-2217(99)00407-5

Tone, K, and Sahoo, B. K. (2003). "Scale, indivisibilities and production function in data envelopment analysis," Int. J. Prod. Econ. 84, 165-192. DOI: 10.1016/S09255273(02)00412-7

Tone, K., and Tsutsui, M. (2009). "Network DEA: A slacks-based measure approach," European Journal of Operational Research, 197(1), 243-252. DOI: /10.1016/j.ejor.2008.05.027

Tone, K., and Tsutsui, M. (2010). "Dynamic DEA: A slacks-based measure approach," Omega, 38(3-4), 145-156. DOI: 10.1016/j.omega.2009.07.003

U.S. Environmental Protection Agency (2019). "Inventory of U.S. greenhouse gas emissions and sinks," Retrieved from (https://www.epa.gov/ghgemissions/inventoryus-greenhouse-gas-emissions-and-sinks), Accessed November, 2019

U.S. EPA (2018). “Greenhouse Gas Reporting Program (GHGRP) - Industrial Waste Landfills" Retrieved from (https://www.epa.gov/ghgreporting/monitoring-checklistsubpart-tt-industrial-waste-landfills), Accessed Feb., 2020

U.S. EPA (2020). "Waste Reduction Model (WARM)," Retrieved from (https://www.epa.gov/warm), Accessed Feb., 2020

U.S. EPA (2016). "WARM Containers, Packaging, and Non-Durable Good Materials Chapters" Retrieved from (https://www.epa.gov/warm/documentation-chaptersgreenhouse-gas-emission-energy-and-economic-factors-used-waste-reduction), Accessed Feb., 2020

Vachon, S. (2012). "Technological capacity and environmental performance: A research note using country level data," Journal of Operations and Supply Chain Management 2012, 21-28. DOI: 10.12660/joscmv1n1p21-28.

Vázquez-Rowe, I., and Iribarren, D. (2015). "Review of life-cycle approaches coupled with data envelopment analysis: Launching the CFP + DEA method for energy policy making," Scientific World Journal. DOI: 10.1155/2015/813921.

Wei, Y. M., Liao, H., and Fan, Y. (2007). "An empirical analysis of energy efficiency in China's iron and steel sector," Energy 32, 2262-2270. DOI: 
10.1016/j.energy.2007.07.007

Wang, Q., Zhou, P., and Zhou, D. (2011). "Efficiency measurement with carbon dioxide emissions: The case of China," Appl. Energy 90, 161-166. DOI: 10.1016/j.apenergy.2011.02.022

WestRock (2016). “Annual Report 2016,” Retrieved from (westrock.com), Accessed April, 2020.

WestRock (2019). “Annual Report 2019," Retrieved from (westrock.com), Accessed April, 2020.

Wu, J., Li, M., Zhu, Q., Zhou, Z. and Liang., L. (2019). "Energy and environmental efficiency measurement of China's industrial sectors: A DEA model with nonhomogeneous inputs and outputs," Energy Economics 78, 468-480. DOI: 10.1016/j.eneco.2018.11.036

Yu, C, Shi, Lei, Wang, Y. T., Chang, Y., and Cheng, B. (2016). "The eco-efficiency of pulp and paper industry in China: An assessment based on slacks-based measure and Malmquist-Luenberger index," Journal of Cleaner Production 127, 511-521. DOI: 10.1016/j.jclepro.2016.03.153.

Zhang, B., Bi, J., Fan, Z., Yuan, Z., and Ge, J. (2008). "Environmental efficiency analysis of industrial system in China: A data envelopment analysis approach," Ecol. Econ. 68, 306-316. DOI: 10.1016/j.ecolecon.2008.03.009

Zhang, H., Liu, H., Bressers, T. A., and Buchanan, K. S. (2011). "Productivity growth and environmental regulations - Accounting for undesirable outputs: analysis of China's thirty provincial regions using the Malmquist-Luenberger index," Ecol. Econ. 70, 2369-2379. DOI: 10.1016/j.ecolecon.2011.07.019

Zhang, J., and Bu, S. (2017). "Measuring allocation efficiency of regional green S\&T resources based on three-stage SBM-DEA - Taking Guilin city as an example," Resour. Dev. Mark 33, 1-7. DOI:10.3969/j.issn.1005-8141.2017.01.001

Zhou, P., Ang, B. W., and Poh, K. L. (2006). "Slack-based efficiency measures for modeling environmental performance," Ecol. Econ. 60 (1), 111-118. DOI: 10.1016/j.ecolecon.2005.12.001

Zhu, J. (2004). "Imprecise DEA via standard linear DEA models with a revisit to a Korean mobile telecommunication company," Operations Research 52(2), 323-329. DOI: $10.1287 /$ opre. 1030.0072

Article submitted: June 15, 2020; Peer review completed: August 3, 2020; Revised version received: August 21, 2020; Accepted: August 22, 2020; Published: August 27, 2020.

DOI: $10.15376 /$ biores. 15.4.7796-7814 